\title{
Influence of Drying in Hyptis pectinata Essential Oil
}

\author{
Núbia Angélica de Ávila Branquinho ${ }^{1}$, Fabiano Guimarães Silva ${ }^{1}$, Osvaldo Resende ${ }^{1}$, \\ Luiz Cláudio Almeida Barbosa ${ }^{2}$, Daniel Emanuel Cabral de Oliveira ${ }^{3} \&$ Rita Cássia Nascimento Pedroso ${ }^{4}$ \\ ${ }^{1}$ IF Goiano, Campus Rio Verde, Brazil \\ ${ }^{2}$ Universidade Federal de Minas Gerais, MG, Brazil \\ ${ }^{3}$ IF Goiano, Campus Iporá, Brazil \\ ${ }^{4}$ Universidade de Franca, SP, Brazil \\ Correspondence: Fabiano Guimarães Silva, Instituto Federal Goiano, Campus Rio Verde, Brazil. E-mail: \\ fabianoifgoiano@gmail.com
}

Received: December 23, 2017

Accepted: January 29, 2018

Online Published: March 15, 2018

doi:10.5539/jas.v10n4p96

URL: https://doi.org/10.5539/jas.v10n4p96

\begin{abstract}
The present study assessed the effects of drying at different temperatures $\left(35,45\right.$ and $\left.55^{\circ} \mathrm{C}\right)$ and air velocities $(1$ and $2 \mathrm{~m} \mathrm{~s}^{-1}$ ) on the content and chemical characteristics of Hyptis pectinata essential oil. Drying was conducted in a fixed-bed dryer, and the temperatures and air velocities were controlled and recorded by an automated system. A $350 \pm 0.12 \mathrm{~g}$ quantity of fresh leaves was used for each of the four repetitions in each dryer. From the material obtained after drying, $60 \mathrm{~g}$ of each repetition was used to extract essential oil by the hydrodistillation method. Dichloromethane was used as the solvent, and anhydrous sodium sulfate was used as the desiccating agent. Gas chromatography in the forms of GC-MS and GC-FID were used for the chemical characterization of the essential oil compounds. Decreasing drying times and decreasing concentrations of essential oils were observed with increasing temperatures. A GC-MS analysis of the essential oil from $H$. pectinata leaves led to the identification of 19 compounds. A sesquiterpene called caryophyllene oxide was the most abundant compound under all drying conditions, with the highest concentration at a temperature of $55{ }^{\circ} \mathrm{C}$, ranging from approximately 42 to $53 \%$.
\end{abstract}

Keywords: caryophyllene oxide, gas chromatography, hydrodistillation, sambaicatá

\section{Introduction}

The Hyptis genus in the Lamiaceae family includes approximately 580 species, and they are distributed throughout the Americas, Occidental Africa, Fiji Island (Oceania), western India, and the Brazilian Cerrado biome (Harley \& Reynolds, 1988). The members of this genus are a source of aromatic essential oils, and they are used for gardening, landscaping and cuisine. Hyptis spp. plants have medicinal properties and are recommended in folk medicine for the treatment of many conditions such as gastrointestinal disorders, skin infections, nasal congestion, fever, colic, inflammation and pain (Bueno, Moreira, Silva, Estevam, \& Marchioro, 2006; Franco et al., 2011a, 2011b). They are also used to treat eye infections and rheumatism (Arnason, Mata, \& Romeo, 2013).

The Hyptis pectinata (L.) Poit species belongs to the Lamiaceae family, is known as "sambaicatá" or "canudinho", and is widely used as a medicinal herb. It is used as a medicinal tea (as an infusion or decoction) for treating skin diseases, gastric diseases, nasopharyngitis, nasal congestion, fever, and other bacterial or fungal infections (Nascimento et al., 2008).

The special metabolism of plants from the Hyptis genus exhibits outstanding variability, demonstrating the predominance of essential oils, which are highly valuable in many communities that employ their therapeutic properties (Oliveira et al., 2011).

There are several factors that can promote alterations in the chemical composition of essential oils, namely, genetic variations, climate, soil composition, seasonality, and harvest and postharvest conditions (Zouari, Ayadi, Fakhfakh, Rebai, \& Zouari, 2012). 
Postharvest procedures have attracted attention from researchers. According to Pimentel, Cardoso, Andrade, Zacaroni, and Guimarães (2012), the essential parameters for the quality of the raw material can vary depending on its origin.

The drying of medicinal species is aimed at minimizing the loss of active principles and delaying their deterioration when it is not possible to use fresh plants. During drying, the air velocity and temperature affect the quantity and quality of active principles that are present in medicinal, aromatic and condiment plants (Melo, Radünz, \& Melo, 2004); i.e., the active principle content could increase or decrease. Decreases in the moisture content can also increase the quantity of active principles in relation to the dry mass.

Changes in the chemical composition occur, especially in relation to the large quantity of volatile compounds found in aromatic plants (Silva \& Casali, 2000). Thus, the drying temperature should be controlled, and studies on its influence are necessary to obtain the most appropriate drying temperature for each species to ensure adequate essential oil contents and chemical compositions (Ebadi, Azizi, Sefidkon, \& Ahmadi, 2015).

Based on this justification, the aim of this study was to verify the influence of drying on the chemical compounds in $H$. pectinata essential oil when the leaves were subjected to three drying temperatures $(35,45$ and $55^{\circ} \mathrm{C}$ ) and two air velocities $\left(1\right.$ and $\left.2 \mathrm{~m} \mathrm{~s}^{-1}\right)$.

\section{Material and Methods}

\subsection{Plant Material}

To obtain $H$. pectinata plants, seedlings were produced in the greenhouse at the Plant Tissue Culture Laboratory (Laboratório de Cultura de Tecidos Vegetais-LCTV) of the Federal Institute of Goiás (Instituto Federal Goiano), Rio Verde Campus. On October 2013, when the seedlings had reached $5 \mathrm{~cm}$ in height, they were transferred to the field at the Plant Nursery of the Federal Institute of Goiás, Rio Verde Campus; they were planted with $20 \mathrm{~cm}$ of plant spacing and $1 \mathrm{~m}$ of row spacing, as shown in Figure 1.

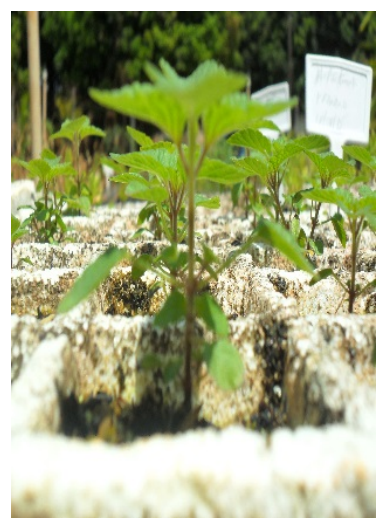

(A)

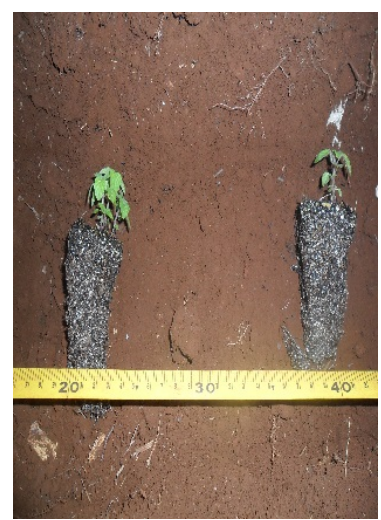

(B)

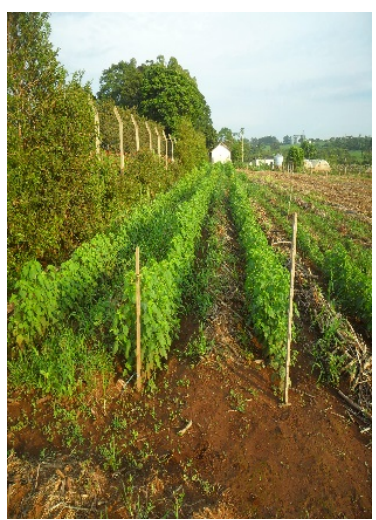

(C)

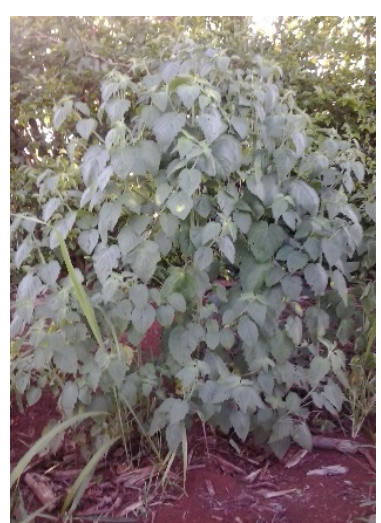

(D)

Figure 1. Hyptis pectinata production. A: $5-\mathrm{cm}$ seedlings produced in the greenhouse; B: seedling transfer to the field, with a plant spacing of $20 \mathrm{~cm}$; C: the plants at 30 days after being transferred to the field; and D: the plants at 60 days after being transferred

The aerial parts of the plants were collected on December 2013 from 7:30 a.m. to 8:00 a.m. The specimens were deposited in the Herbarium at the Federal Institute of Goiás, Rio Verde Campus under record number 492.

\subsection{Drying}

The plants were taken to the Laboratory of Postharvest Vegetal Products at the Federal Institute of Goiás, Rio Verde Campus, where they were subjected to leaf removal and selection. Their moisture content was determined before and after drying, according to the method developed by ASAE (2000) for fodder plants, in a forced air circulation oven for 24 hours.

Fixed-bed dryers were used to dry the $H$. pectinata leaves, and these dryers were able to provide drying air at controlled flow rate by a drawer register and the temperature by electrical resistances. They were connected to an automated system that managed and stored data during the drying, with temperatures of 35,45 and $55^{\circ} \mathrm{C}$ and air flow rates of $1 \mathrm{~m} \mathrm{~s}^{-1}$ and $2 \mathrm{~m} \mathrm{~s}^{-1}$. Each dryer contained a centrifugal fan with $1.5 \mathrm{HP}$ and a rotation of 1,720 rpm, 
and each had a set of 1,500-watt electrical resistors to heat the air, for a total of 6,000 watts. Each dryer was manufactured with size-16 metal plate walls, the drying chamber had a volume of $0.216 \mathrm{~m}^{3}$, with four removable rectangular trays, and its dimensions were $0.28 \times 0.28 \times 0.15 \mathrm{~m}$, with a perforated bottom. The dryers also had 6 pendulum temperature sensors that were positioned before and after the resistors and inside each tray. The trays were filled with replicates containing $350 \pm 0.12 \mathrm{~g}$ of leaves for the two air velocities.

During the drying process, the samples were periodically weighed until they reached a constant mass. At the end of each process, part of the material was conditioned in metal capsules and placed in the forced air circulation oven at $103{ }^{\circ} \mathrm{C}$ for 24 hours to determine the final moisture content. The other part of the plant material was stored in plastic bags at B.O.D. (Biochemical Oxygen Demand) at $1{ }^{\circ} \mathrm{C}$ until the moment when the essential oil was extracted.

\subsection{Statistical Analysis}

The experiment was conducted using a completely randomized design in a $3 \times 2$ factorial scheme (three drying temperatures and two air velocities) with four repetitions, for a total of 24 experimental units. SISVAR software (Ferreira, 2011) was used; the data related to the treatment effects were subjected to an analysis of variance (ANOVA), and the means were analyzed by Tukey's test at 5\% significance.

\subsection{Extraction and Analyses of Volatile Oils}

Oil extraction was conducted at the Plant Tissue Culture Laboratory by the hydrodistillation method with a Clevenger apparatus that was adapted to a 3-L distillation flask and a thermostatized bath. After that, 60-g samples of the dry leaves were extracted for 50 minutes, starting at the beginning of boiling. After the hydrolate was obtained, the oil was extracted in triplicate in a decantation funnel, with dichloromethane. The organic fractions were dried with anhydrous sodium sulfate $(3.0 \mathrm{~g})$, which was allowed to react for 24 hours. The salt was removed by simple filtration, and the solvent was evaporated at room temperature under the fume hood. Next, the oil was transferred to a previously weighed amber flask to calculate the oil yield.

Chemical analyses of the essential oils were performed in a Shimadzu GC-17A gas chromatographer equipped with a flame ionization detector (FID) and SPB-5 fused silica capillary column $(30 \mathrm{~m} \times 0.25 \mathrm{~mm}$, film thickness of $0.25 \mu \mathrm{m}$ ) with He carrier gas; it had a $1.8 \mathrm{~mL} \mathrm{~min}^{-1}$ flow, an injector temperature of $220{ }^{\circ} \mathrm{C}$ and a detector temperature of $240{ }^{\circ} \mathrm{C}$. The initial temperature of the column was $40{ }^{\circ} \mathrm{C}$, and it was isothermal for 44 min, followed by heating at $3{ }^{\circ} \mathrm{C} \mathrm{min}{ }^{-1}$ until reaching $240{ }^{\circ} \mathrm{C}$ and then remaining isothermal for $15 \mathrm{~min}$. The sample injection volume was $1.0 \mu \mathrm{L}\left(10 \mathrm{mg} \mathrm{mL}^{-1}\right.$ in $\left.\mathrm{CH}_{2} \mathrm{Cl}_{2}\right)$, and the split ratio was 1:10; the column pressure was 115 $\mathrm{kPa}$, and the total run time was $70 \mathrm{~min}$. The concentration of each constituent was calculated by taking the percentage of the corresponding peak area in relation to the total area of all the peaks in the chromatogram.

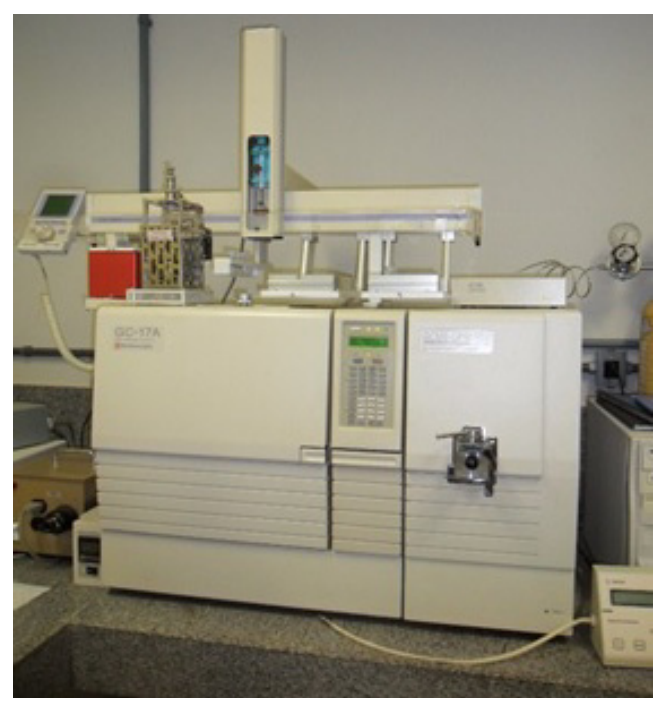

(A)

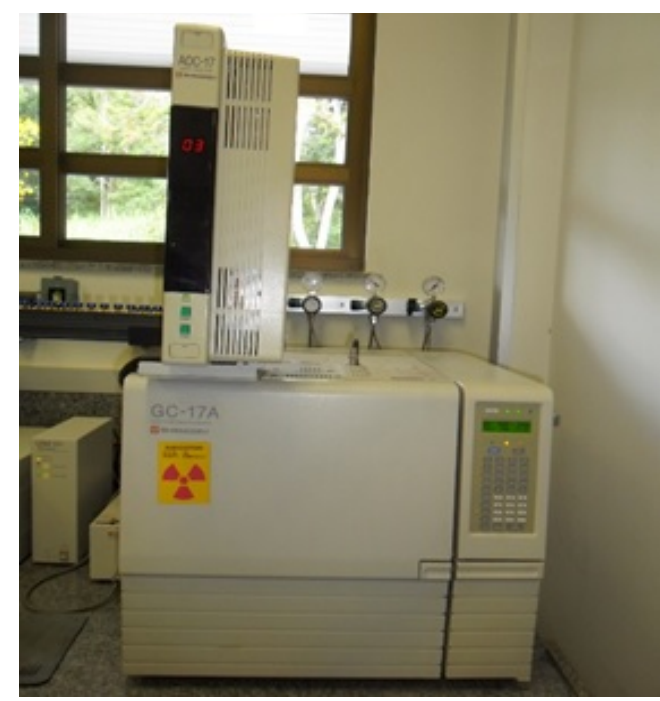

(B)

Figure 2. Gas chromatography apparatus: A: Shimadzu GCMS-QP5050A Chromatograph; B: Shimadzu GC-17A Chromatograph equipped with a flame ionization detector (FID) 
Shimadzu GCMS-QP5050A equipment was used for identification, as observed in Figure 2A; this gas chromatograph was equipped with an RTX-5 fused silica column $(30 \mathrm{~m} \times 0.25 \mathrm{~mm}$, film thickness of $0.25 \mu \mathrm{m})$ with a mass detector. The chromatographic conditions were identical to those used in the GC-FID, with a column pressure of $100 \mathrm{kPa}$, the electron impact ionization process $(70 \mathrm{eV})$ and a scan range of 30 to $700 \mathrm{Da}$.

Compound identification was performed by comparing the mass spectra obtained experimentally with those available in the database of the machine (Wiley seventh edition, NIST 08 and NIST 11) and by comparing the retention index calculated from the injection of a mixture of linear alkanes $\left(\mathrm{C}_{9}-\mathrm{C}_{26}\right)$ with those from the literature (Adams, 1995). The identifications were also confirmed by studying the mass fragments observed in each spectrum.

\section{Results and Discussion}

The H. pectinata leaves displayed a moisture content of $4.68 \pm 0.04$ dry basis. After the leaves dried, the moisture contents were reduced to $0.11,0.09$, and 0.09 dry basis at 35,45 and $55{ }^{\circ} \mathrm{C}$, respectively, at a velocity of $1 \mathrm{~m} \mathrm{~s}^{-1}$. For a velocity of $2 \mathrm{~m} \mathrm{~s}^{-1}$, the moisture contents were $0.10,0.10$ and 0.10 dry basis for temperatures of 35,45 and $55^{\circ} \mathrm{C}$, respectively. The final moisture contents fit the values recommended by different pharmacopoeias, which ranged from 0.09 to 0.16 dry basis.

The drying times were reduced with increasing temperature and drying air velocity, as observed in Figure 3.

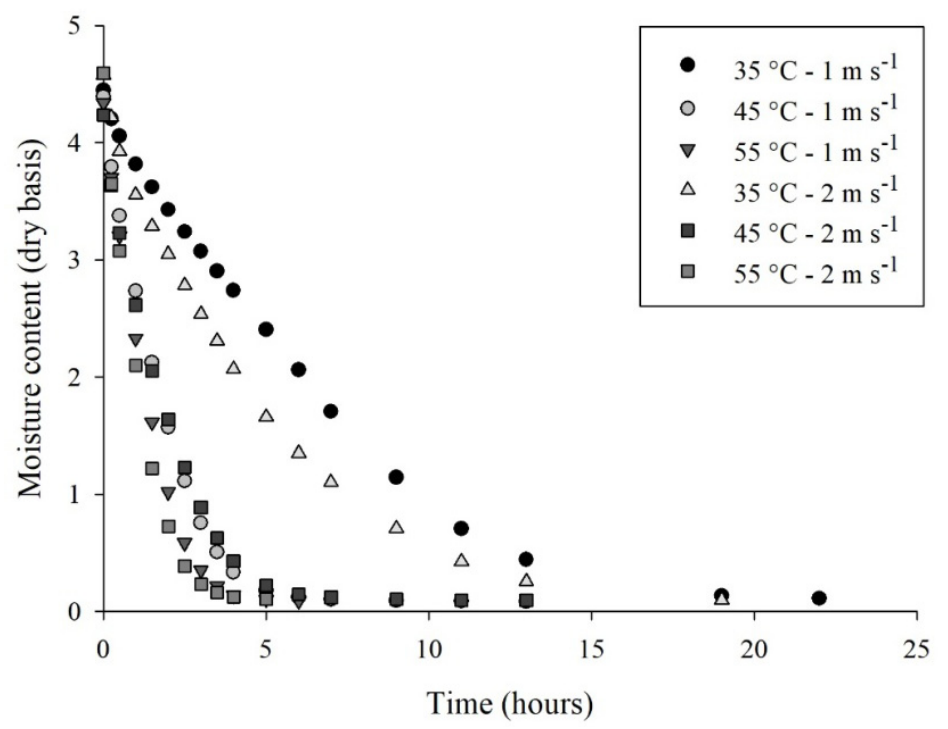

Figure 3. Drying curve of Hyptis pectinata when the leaves were dried at 35,45 and $55^{\circ} \mathrm{C}$ at velocities of 1 and $2 \mathrm{~m} \mathrm{~s}^{-1}$

The drying times for 35,45 and $55^{\circ} \mathrm{C}$ were 22,13 and 6 hours at $1 \mathrm{~m} \mathrm{~s}^{-1}$ and 19,13 and 5 hours at $2 \mathrm{~m} \mathrm{~s}^{-1}$. As observed in Figure 3, the drying time at $35{ }^{\circ} \mathrm{C}$ was longer than the times for the other temperatures. In operational terms, this longer time could hinder the drying process because of the increased electricity expense, in addition to an increased possibility of the development of microorganisms in the plant material (Barbosa, Barbosa, Melo, Botelho, \& Santos, 2006). This factor can also lead to alterations in the oil contents and the chemical composition because the essential oils are rich in volatile compounds that could be lost if the plant material is exposed to high temperatures for a long time.

Table 1 shows the statistical analysis for the essential oil from the $H$. pectinata leaves subjected to different temperatures and drying air velocities. 
Table 1 . Analysis of variance for the oil contents during drying in $H$. pectinata leaves

\begin{tabular}{lll}
\hline Variable & Degrees of Freedom & Mean Squared \\
\hline Velocity & 1 & $0.000160^{\mathrm{ns}}$ \\
Temperature & 2 & $0.001747^{* *}$ \\
Velocity $\times$ Temperature & 2 & $0.000201 \mathrm{~ns}$ \\
\hline Coefficient of Variation $(\%)$ & 17.29 & \\
\hline
\end{tabular}

Note. ${ }^{* *}$ Significant at $1 \%$ by $\mathrm{F}$ test; ${ }^{\text {ns }}$ Non-significant.

Table 1 indicates that the drying air velocity, as well as the interaction between the velocity and the temperature, did not influence the essential oil content. Therefore, the analysis of the temperature effect was performed in isolation. The drying temperature influenced the essential oil yield, with a decrease between 35 and $55{ }^{\circ} \mathrm{C}$, which corroborates the results obtained by Pimentel et al. (2012), who reported a decrease in Piper piscatorum essential oils when the drying temperature was increased from 30 to $40{ }^{\circ} \mathrm{C}$. Barbosa et al. (2006) subjected Lippia alba to air temperatures that varied from room temperature $\left(25^{\circ} \mathrm{C}\right)$ to $80{ }^{\circ} \mathrm{C}$, and they observed a decrease in the essential oil content from 12 to $17 \%$ in comparison with that obtained for the fresh plant.

The means observed in Table 2 can vary by \pm 0.02 at $35^{\circ} \mathrm{C}$ and 0.01 at 45 and $55^{\circ} \mathrm{C}$ for both velocities.

Table 2. Means of the essential oil content $(\% \mathrm{db})$ during the drying of $H$. pectinata leaves

\begin{tabular}{llll}
\hline \multirow{2}{*}{ Temperature $\left({ }^{\circ} \mathrm{C}\right)$} & \multicolumn{2}{c}{ Velocities $\left(\mathrm{m} \mathrm{s}^{-1}\right)$} & Mean \\
\cline { 2 - 3 } & 1 & 2 & $0.1117 \mathrm{~A}$ \\
35 & 0.1038 & 0.1197 & $0.0957 \mathrm{AB}$ \\
55 & 0.0940 & 0.0974 & $0.0822 \mathrm{~B}$ \\
\hline
\end{tabular}

Note. The same letters in the same column do not differ between themselves according to Tukey's test at $5 \%$ significance.

The resulting means show a reduction in the oil content at temperatures between 35 and $55^{\circ} \mathrm{C}$, as observed in Table 2. Radünz et al. (2003) observed that drying treatments at room temperature (approximately $25^{\circ} \mathrm{C}$ ), 40,55 and $70{ }^{\circ} \mathrm{C}$ influenced the essential oil yield, presenting reductions relative to those of the fresh plant, except at $55^{\circ} \mathrm{C}$. However, in analyzing the drying treatments, the yield increased with increasing drying air temperature.

These data corroborate the results by Arrigoni-Blank et al. (2010), who emphasized the need for studies involving agronomic techniques for each species because of behavioral differences.

The GC/MS analysis of the essential oil from H. pectinata leaves led to the identification of 19 components. The major essential oil component was caryophyllene oxide under all drying conditions, with a mean concentration of $49 \pm 5 \%$. The other primary compounds included humulene epoxide II, $\alpha$-cadinol, calamusenone and $\beta$-elemene, with concentrations below $5 \%$. The presence of caryophyllene oxide as the primary component of $H$. pectinata essential oil was also observed by other authors (Raymundo et al., 2011; Santos et al., 2008).

The trans-caryophyllene compound was found at concentrations above $5 \%$; however, it was only observed at the $1 \mathrm{~m} \mathrm{~s}^{-1}$ velocity and at temperatures of 35 and $55^{\circ} \mathrm{C}$, with concentrations of $10.12 \pm 0.79$ and $5.89 \pm 1.09 \%$, respectively. The $35{ }^{\circ} \mathrm{C}$ temperature could cause lower volatility, whereas $55^{\circ} \mathrm{C}$ allows for a shorter exposure of the plant material to drying conditions, which could also lead to the lower volatilization of the compounds.

Table 3 shows the identified compounds and their concentrations (\%) for each treatment. 
Table 3. Chemical composition and concentration of the constituents of Hyptis pectinata essential oils at 35, 45 and $55^{\circ} \mathrm{C}$ and air velocities of $1 \mathrm{~m} \mathrm{~s}^{-1}$ and $2 \mathrm{~m} \mathrm{~s}^{-1}$

\begin{tabular}{|c|c|c|c|c|}
\hline AI TAB & COMPOUND & $35^{\circ} \mathrm{C}$ & $45^{\circ} \mathrm{C}$ & $55^{\circ} \mathrm{C}$ \\
\hline \multicolumn{5}{|l|}{$1 m^{-1}$} \\
\hline 1374 & Alpha-Copaene & $0.46 \pm 0.03$ & - & - \\
\hline 1387 & Beta-bourbonene & $1.02 \pm 0.08$ & - & - \\
\hline 1389 & Beta-Elemene & $2.05 \pm 0.17$ & $2.02 \pm 0.30$ & $2.08 \pm 0.22$ \\
\hline 1417 & Trans-Caryophyllene & $10.12 \pm 0.79$ & - & $5.89 \pm 1.09$ \\
\hline 1452 & Alpha-Humulene & $1.25 \pm 0.27$ & - & - \\
\hline 1484 & Germacrene D & $0.62 \pm 0.03$ & - & $2.93 \pm 0.13$ \\
\hline 1498 & Selinene $<\alpha->$ & $0.67 \pm 0.02$ & - & - \\
\hline 1559 & Germacrene B & $2.28 \pm 0.36$ & - & - \\
\hline 1561 & Nerolidol $<(\mathrm{E})$ - $>$ & $0.33 \pm 0.01$ & - & - \\
\hline 1571 & Apofarnesol $<(Z)$-dihydro- $>$ & - & $0.67 \pm 0.04$ & $0.67 \pm 0.01$ \\
\hline 1577 & Spathulenol & $0.62 \pm 0.07$ & - & - \\
\hline 1582 & Caryophyllene oxide & $42.71 \pm 5.77$ & $46.36 \pm 2.71$ & $52.91 \pm 2.23$ \\
\hline 1608 & Humulene Epoxide II & $4.33 \pm 0.56$ & $4.52 \pm 0.38$ & $4.53 \pm 0.23$ \\
\hline 1638 & Cadinol <epi- $\alpha->$ (tau.-Cadinol) & $0.89 \pm 0.02$ & $1.15 \pm 0.13$ & $0.94 \pm 0.12$ \\
\hline 1652 & Cadinol $<\alpha->$ & $2.98 \pm 0.41$ & $1.90 \pm 0.28$ & $3.57 \pm 0.28$ \\
\hline 1676 & Calamusenone & $3.40 \pm 0.94$ & $11.06 \pm 1.11$ & $11.31 \pm 0.88$ \\
\hline 1684 & Bisabolone oxide $\mathrm{A}<\alpha->$ & $1.50 \pm 0.30$ & $2.18 \pm 0.17$ & $1.93 \pm 0.17$ \\
\hline 1715 & Pentadecanal & $2.02 \pm 0.21$ & $1.95 \pm 0.18$ & $1.65 \pm 0.14$ \\
\hline 1748 & $\mathrm{NI}$ & $1.63 \pm 0.39$ & $1.91 \pm 0.11$ & $1.23 \pm 0.16$ \\
\hline 1775 & $\mathrm{NI}$ & $2.78 \pm 0.95$ & $2.51 \pm 0.15$ & $1.55 \pm 0.15$ \\
\hline 1843 & Hexahydro farnesyl acetone & $2.84 \pm 0.37$ & $2.44 \pm 0.15$ & $1.92 \pm 0.10$ \\
\hline 1879 & 1-Hexadecanol & $1.08 \pm 0.08$ & $1.72 \pm 0.23$ & $1.44 \pm 0.24$ \\
\hline 1889 & Heptadecadienal & $2.01 \pm 0.12$ & $1.81 \pm 0.34$ & \\
\hline 1910 & Farnesyl acetone & $1.63 \pm 0.19$ & $1.36 \pm 0.11$ & $1.26 \pm 0.11$ \\
\hline \multirow[t]{2}{*}{1921} & Methyl Hexadecanoate & $1.67 \pm 0.25$ & & \\
\hline & Total identified & 90.89 & 83.56 & 95.81 \\
\hline \multicolumn{5}{|l|}{$2 m s^{-1}$} \\
\hline 1374 & Alpha-Copaene & - & - & - \\
\hline 1387 & Beta-bourbonene & $1.13 \pm 0.18$ & $1.07 \pm 0.07$ & - \\
\hline 1389 & Beta-Elemene & $1.65 \pm 0.23$ & $2.63 \pm 0.69$ & - \\
\hline 1417 & Trans-Caryophyllene & - & - & - \\
\hline 1452 & Alpha-Humulene & - & - & - \\
\hline 1484 & Germacrene D & & $1.00 \pm 0.13$ & - \\
\hline 1498 & Selinene $<\alpha->$ & - & - & - \\
\hline 1559 & Germacrene B & $2.51 \pm 0.19$ & $2.66 \pm 0.22$ & $2.98 \pm 0.41$ \\
\hline 1561 & Nerolidol $<(\mathrm{E})$ - $>$ & - & - & - \\
\hline 1571 & Apofarnesol $<(Z)$-dihydro- $>$ & - & - & - \\
\hline 1577 & Spathulenol & - & - & - \\
\hline 1582 & Caryophyllene oxide & $46.83 \pm 3.83$ & $48.00 \pm 3.88$ & $55.43 \pm 7.78$ \\
\hline 1608 & Humulene Epoxide II & $4.35 \pm 0.43$ & $4.01 \pm 0.46$ & $4.31 \pm 0.58$ \\
\hline 1638 & Cadinol <epi- $\alpha->$ (tau.-Cadinol) & $1.06 \pm 0.13$ & $1.67 \pm 0.28$ & $0.71 \pm 0.04$ \\
\hline 1652 & Cadinol $<\alpha->$ & $3.02 \pm 0.24$ & $3.10 \pm 0.33$ & $1.87 \pm 0.19$ \\
\hline 1676 & Calamusenone & $2.86 \pm 0.37$ & $3.24 \pm 0.18$ & $3.35 \pm 0.13$ \\
\hline 1684 & Bisabolone oxide $\mathrm{A}<\alpha->$ & $1.51 \pm 0.19$ & $1.49 \pm 0.25$ & $2.78 \pm 0.27$ \\
\hline 1715 & Pentadecanal & $1.96 \pm 0.19$ & $1.64 \pm 0.23$ & $1.98 \pm 0.20$ \\
\hline 1748 & $\mathrm{NI}$ & $1.51 \pm 0.26$ & $1.53 \pm 0.12$ & $1.18 \pm 0.09$ \\
\hline 1775 & $\mathrm{NI}$ & $3.79 \pm 0.58$ & $3.53 \pm 0.71$ & $2.38 \pm 0.29$ \\
\hline 1843 & Hexahydro farnesyl acetone & $2.77 \pm 0.20$ & $2.72 \pm 0.19$ & $2.69 \pm 0.15$ \\
\hline 1879 & 1-Hexadecanol & $0.95 \pm 0.05$ & $2.04 \pm 0.39$ & $3.38 \pm 0.31$ \\
\hline 1889 & Heptadecadienal & & & $1.74 \pm 0.09$ \\
\hline 1910 & Farnesyl acetone & $1.79 \pm 0.12$ & $1.49 \pm 0.11$ & \\
\hline \multirow[t]{2}{*}{1921} & Methyl Hexadecanoate & $1.55 \pm 0.12$ & $1.56 \pm 0.13$ & \\
\hline & Total identified & 79.24 & 83.38 & 84.78 \\
\hline
\end{tabular}

Note. AI TAB: arithmetic index from tables, NI: Not identified. 
Table 3 shows that it was possible to identify the largest number of compounds at a temperature of $35^{\circ} \mathrm{C}$. However, the ideal temperature for obtaining higher concentrations of the major compound was $55{ }^{\circ} \mathrm{C}$ under both drying air velocities.

The identified chemical compounds belonged exclusively to the sesquiterpene class. Raymundo et al. (2011) also highlighted this fact and justified the possible presence of monoterpenes in the essential oil from $\mathrm{H}$. pectinata, but at undetectable quantities.

Differences in the essential oil compositions in the same species can occur because of many factors. These results are in accordance with studies on the drying of different species, such as thyme and sage, as performed by other authors who also reported changes in the essential oil components of various plants that were caused by drying (Venskutonis, 1997). Arrigoni-Blank et al. (2010) reported that the differences between the chemical compositions can be justified because each genotype responds differently to the given environmental conditions and also to the drying process, which eliminates water from the material and increases the percentage of active principles in comparison with the fresh plant.

Jesus et al. (2016) also performed the drying of Hyptis pectinata samples, but at a single temperature of $40^{\circ} \mathrm{C}$ for four days, without variations in air drying drier rate. The oil was extracted by steam distillation and stored the samples of oils obtained at temperatures of $\pm 32^{\circ} \mathrm{C}$ and $-20^{\circ} \mathrm{C}$. The objective of the work of Jesus et al. (2016) was to evaluate the influence of the time and storage temperature of the oils obtained, and therefore performed chromatographic analyzes in 11 time periods over 360 days, diverging from this work, which aimed to verify the influence of the drying procedures on the chemical composition of Hyptis pectinata essential oil. In spite of this, the two studies verified the expressive presence of the compound cation of caryophyllene. While in this work the caryophyllene oxide showed the major compound, with its higher concentrations at $55^{\circ} \mathrm{C}$, in the experiments of Jesus et al. (2016) this was the compound with the second highest concentration and remained more stable when stored in a freezer at a temperature of $-20^{\circ} \mathrm{C}$. In this way, we can see the instability of the chemical components in the essential oil when submitted to different temperatures.

\section{Conclusions}

The drying process promotes reductions in the drying times and in the contents of $H$. pectinata essential oils. The highest oil contents were obtained at $35{ }^{\circ} \mathrm{C}$, with caryophyllene oxide being the major compound under all drying conditions, exhibiting the highest concentrations of $52.91 \pm 2.23$ and $55.43 \pm 7.78 \%$ at $55{ }^{\circ} \mathrm{C}$ for air velocities of $1 \mathrm{~m} \mathrm{~s}^{-1}$ and $2 \mathrm{~m} \mathrm{~s}^{-1}$, respectively.

\section{References}

Adams, R. P. (1995). Identification of essencial oil componentes by gas chromatography/mass spectroscopy. Carol Stream, IL: Allured Publishing Corporation.

Arnason, J. T., Mata, R., \& Romeo, J. T. (2013). Phytochemistry of Medicinal Plants-Recente advances in Phytochemistry. Springer Verlag NY.

Arrigoni-Blank, M. F., Blank, A. F., Costa, A. G., Alves, P. B., \& Costa, A. S. (2010). Influência do horário de colheita e de secagem no óleo essencial de Hyptis pectinata L. Poit (Lamiaceae). Scientia Plena, 6(10), 1-5.

ASAE. (2000). Standards engineering practices data: Moisture measurement ASAE S358.2 DEC99. St. Joseph: American Society of Agricultural Engineers.

Barbosa, F. F., Barbosa, L. C. A., Melo, E. C., Botelho, F. M., \& Santos, R. H. S. (2006). Influência da temperatura do ar de secagem sobre o teor e a composição química do óleo essencial de Lippia alba (mill) n. e. brown. Química Nova, 29(6), 1221-1225. https://doi.org/10.1590/S0100-40422006000600014

Bueno, A. X., Moreira, A. T. S., Silva, F. T., Estevam, C. S., \& Marchioro, M. (2006). Effects of the aqueous extract from Hyptis pectinata leaves on rodent central nervous system. Revista Brasileira de Farmacognosia, 16(3), 317-323. https://doi.org/10.1590/S0102-695X2006000300007

Ebadi, M. T., Azizi, M., Sefidkon, F., \& Ahmadi, N. (2015). Influence of different drying methods on drying period, essential oil content and composition of Lippia citriodora Kunth. Journal of Applied Research on Medicinal and Aromatic Plants, 2(4), 182-187. https://doi.org/10.1016/j.jarmap.2015.06.001

Ferreira, D. F. (2011). Sisvar: Um sistema computacional de análise estatística. Ciência e Agrotecnologia, 35(6) 1039-1042. https://doi.org/10.1590/S1413-70542011000600001 
Franco, C. R. P., Alves, P. B., Andrade, D. M., Jesus, H. C. R., Silva, E. J. S., Santos, A. B., ... Quintans-Junior, L. J. (2011a) Essential oil composition and variability in Hyptis fruticosa. Revista Brasileira de Farmacognosia, 21(1), 24-32. https://doi.org/10.1590/S0102-695X2011005000034

Franco, C. R., Antoniolli, A. R., Guimarães, A. G., Andrade, D. M., Jesus, H. C., Alves, P. B., Bannet, L. E., ... Botelho, M. A. (2011b). Bioassay-guided evaluation of antinociceptive properties and chemical variability of the essential oil of Hyptis fruticosa. Phytotherapy Research, 25(11), 1693-1699. https://doi.org/ 10.1002/ptr.3455

Harley, R. M., \& Reynolds, T. (1992). Advances in Labiate science. Kew, UK: The Royal Botanic Gardens.

Jesus, A. S., Blank, A. F., Alves, M. F., Arrigoni-Blank, M. F., Lima, R. N., \& Alves, P. B. (2016). Influence of storage time and temperature on the chemical composition of the essential oil of Hyptis pectinata L. Poit. Revista Brasileira de Plantas Medicinais, 18(Suppl. 1), 336-340. https://doi.org/10.1590/1983-084X/ $15 \_177$

Melo, E. C., Radünz, L. L., \& Melo, R. C. A. (2004). Influência do processo de secagem na qualidade de plantas medicinais-Revisão. Engenharia na Agricultura, 12(4), 307-315.

Nascimento, P., Alviano, W., Nascimento, A., Santos, P., Arrigoni-Blank, M., Jesus, R. de, ... Trindade, R. (2008). Hyptis pectinata essential oil: chemical composition and anti-Streptococcus mutans activity. Oral Diseases, 14(6), 485-489. https://doi.org/10.1111/j.1601-0825.2007.01405.x

Oliveira, L. M., Nepomuceno, C. F., Freitas, N. P., Pereira, D. M. S., Silva, G. S., \& Lucchese, A. M. (2011). Vegetative propagation of Hyptis leucocephala Mart. ex Benth. and Hyptis platanifolia Mart. ex Benth. (Lamiaceae). Brazilian Journal of Medicinal Plants, 13(1), 73-78. https://doi.org/10.1590/S1516-05722 011000100011

Pimentel, F. A., Cardoso, M. G., Andrade, M. A., Zacaroni, L. M., \& Guimarães, L. G. L. (2012). Influência da secagem sobre o rendimento e composição química dos compostos voláteis das raízes de Piper piscatorum trel. \& yunck. (Piperaceae). Química Nova, 35(4), 715-718. https://doi.org/10.1590/S0100-404220120 00400011

Radünz, L. L., Melo, E. C., Berbert, P. A., Barbosa, L. C. A., Santos, R. H. S., \& Rocha, R. P. (2003). Influência da temperatura do ar de secagem na quantidade de óleo essencial extraído de guaco (Mikania glomerata Sprengel). Revista Brasileira de Armazenamento, 28(2), 41-45.

Raymundo, L. J., Guilhon, C. C., Alviano, D. S., Matheus, M. E., Antoniollic, A. R., Cavalcanti, S. C., ... Fernandes, P. D. (2011). Characterisation of the anti-inflammatory and antinociceptive activities of the Hyptis pectinata (L.) Poit essential oil. Journal of Ethnopharmacology, 134(3), 725-732. https://doi.org/ 10.1016/j.jep.2011.01.027

Santos, P. O., Costa, M. de J. C., Alves, J. A. B., Nascimento, P. F. C., Melo, D. L. F. M., Barbosa Jr., A. M., ... Nascimento, M. P. F. (2008). Chemical composition and antimicrobial activity of the essential oil of Hyptis pectinata (L.) Poit. Química Nova, 31(7), 1648-1652. https://doi.org/10.1590/S0100-40422008000700009

Silva, F., \& Casali, V. W. D. (2000) Plantas medicinais e aromáticas: Pós-colheita e óleos essenciais. Viçosa: Arte e Livros.

Venskutonis, P. R. (1997). Effect of drying on the volatile constituents of thyme (Thymus vulgaris L.) and sage (Salvia officinalis L.). Food Chemistry, 59(2), 219-227. https://doi.org/10.1016/S0308-8146(96)00242-7

Zouari, N., Ayadi, I., Fakhfakh, N., Rebai, A., \& Zouari, S (2012). Variation of chemical composition of essential oils in wild populations of Thymus algeriensis Boiss. et Reut., a North African endemic Species. Lipids in Health and Disease, 11, 28. https://doi.org/10.1186/1476-511X-11-28

\section{Copyrights}

Copyright for this article is retained by the author(s), with first publication rights granted to the journal.

This is an open-access article distributed under the terms and conditions of the Creative Commons Attribution license (http://creativecommons.org/licenses/by/4.0/). 